\title{
RETRATO DEL ARTISTA COMO PERRO ROMÁNTICO: LA POESÍA DE ROBERTO BOLAÑO
}

\author{
LuIS BAGUÉ QuíleZ \\ UNIVERSIDAD DE MURCIA
}

\section{Un POETA LLAMADo Bolaño}

Cuando acaban de cumplirse cinco años de su muerte, Roberto Bolaño (Santiago de Chile, 1953-Barcelona, 2003) funciona como paradigma de una escritura que se ha alzado hasta las hornacinas del canon sin abdicar de su contemporaneidad ni renunciar a su carácter subversivo. No obstante, a menudo se olvida que en él confluyeron un brillante narrador y un poeta notable. Esta última faceta se ha visto oscurecida por la fuerza de títulos como Los detectives salvajes (1998), Nocturno de Chile (2000) o 2666 (2004), por citar sólo sus tres novelas mayores. La prosa torrencial de Bolaño ha provocado que su poesía se analice con cierta displicencia, como un pasatiempo literario que poco o nada puede sumar a sus logros como narrador.

Sin embargo, Bolaño no fue de ningún modo un poeta ocasional. Ni su lírica puede circunscribirse a un periodo concreto de su biografía ni debe 
entenderse como una labor al margen de su narrativa. Al contrario, hay un diálogo constante entre ambas parcelas que se advierte en la continuidad de temas, motivos y estilos. ${ }^{1}$ Con un dejo de ironía, el autor explicaba su decisión de cultivar la prosa por motivos exclusivamente económicos: "Nunca he dejado de escribir poesía. Lo que pasa es que cada día escribo menos poesía por razones obvísimas: el dinero lo gano con la prosa". ${ }^{2}$ Más allá de la boutade, lo cierto es que la progresiva importancia de Bolaño como prosista acabaría por lastrar su evolución como poeta. La disciplina que él mismo se impuso - publicar un libro en prosa al año, lo que cumplió desde 1996 hasta su muerte en 2003 resultaba incompatible con la dedicación que exige la poesía. De hecho, el corpus lírico del autor puede darse casi por concluido alrededor de 1993, aunque la publicación de la mayoría de sus poemarios se produjera en fechas más tardías y periódicamente fueran apareciendo nuevas composiciones en cuadernos y revistas. Para Bolaño, la poesía es una Ítaca particular a la que regresa cuando necesita recluirse tras las trincheras del egotismo o articular una resistencia silenciosa frente a las circunstancias exteriores.

Estas precisiones no significan que la escritura poética de Bolaño no sufriera variaciones a lo largo del tiempo. Su prehistoria literaria se inicia en Ciudad de México, donde la familia de Bolaño se trasladó en 1968, cuando él tenía quince años. Por entonces, entra en contacto con otros jóvenes aspirantes a escritores y funda, junto con Mario Santiago, el movimiento infrarrealista. Dicho movimiento es el origen del realismo visceral en el que militan el Arturo Belano y el Ulises Lima de Los detectives salvajes. Desde sus comienzos, el infrarrealismo se vio como una práctica revulsiva antes que como una vertiente estética con rasgos propios. Bajo el pretexto de dinamitar los cimientos de la cultura oficial, esta corriente alimentaba una literatura de la desesperanza

\footnotetext{
${ }^{1}$ En su "Presentación" de Los perros románticos, sostiene Pere Gimferrer: “en Bolaño, la narrativa en prosa es una forma, apenas enmascarada, de poema e incluso de antipoema. Sus ficciones, en modo alguno realistas salvo como metáfora y parodia, no ya de la realidad, sino de sí mismas, en la fecunda frontera ambigua en que colindan el pastiche y el homenaje, son tan poéticas como narrativos son sus poemas/antipoemas"; en Roberto Bolaño, Los perros románticos. Poemas 19801998, Barcelona, El Acantilado, 2006, p. 7.

${ }^{2}$ En Jorge Herralde, Para Roberto Bolaño, Barcelona, El Acantilado, 2005, p. 56. El propio Herralde, que fue el editor de la mayor parte de la obra de Bolaño, insiste en este argumento en otro fragmento del homenaje: "Y sin dejar de cultivar la poesía [Bolaño] decidió convertirse en novelista y así garantizar el futuro de su familia (una idea a priori pintoresca, pero finalmente acertada), y empieza a presentarse a toda clase de concursos literarios en las más diversas provincias españolas" (p. 34).
} 
inspirada por el espíritu disolvente de los ismos de entreguerras. Definido por Bolaño como una suerte de "Dadá a la mexicana", el infrarrealismo cerraba filas en torno a la concepción del poema como un artefacto y de la literatura como un happening perpetuo. ${ }^{3}$ A pesar de su aparente desconexión con otras tendencias, el infrarrealismo participaba del entorno teórico-crítico del momento, donde convivían la libertad interpretativa auspiciada por Susan Sontag, la sociología comunicativa de McLuhan y el pensamiento fragmentario postulado por Umberto Eco.

Los integrantes originarios del infrarrealismo fueron Mario Santiago, Cauhtémoc Méndez, Juan Esteban Harrington, José Peguero, Guadalupe Ochoa, Bruno Montané y Bolaño ${ }^{4}$. Entre las tentativas iniciales del grupo cabe destacar el Primer Manifiesto Infrarrealista, "Déjenlo Todo, Nuevamente", firmado en 1976. En él se ofrece una cosmovisión bastante heterogénea, que oscila entre el empuje revolucionario, el malditismo romántico y la ingenuidad juvenil. Su principal aportación consiste en no renunciar a una perspectiva realista, si bien filtrada a través de una iconografía ajena a los colectivismos sociales. De hecho, la llamada a la movilización del proletariado que abre el texto se diluye poco a poco en un pesimismo histórico que presagia la actitud nihilista y las consignas No Future del movimiento punk:

La muerte del cisne, el último canto del cisne, el último canto del cisne negro, NO ESTÁN en el Bolshoi sino en el dolor y la belleza insoportables de las calles. Un arcoiris que principia en un cine de mala muerte y que termina en una fábrica en huelga. Que la amnesia nunca nos bese en la boca. Que nunca nos bese. Soñábamos con utopía y nos despertamos gritando. Un pobre vaquero solitario que regresa a su casa, que es la maravilla.

\footnotetext{
${ }^{3}$ En una entrevista con Bolaño, Carmen Boullosa recordaba las estridentes irrupciones de los infrarrealistas en la vida literaria mexicana: “Eran el terror del mundo literario [...]. Ustedes estaban ahí para convencer al medio literario de que no podíamos tomarnos en serio lo que no era legítimamente serio, que en la poesía - desdiciendo el dicho chileno - de lo que se trataba era precisamente de aventarse a precipicios"; "Carmen Boullosa entrevista a Roberto Bolaño", en Celina Manzoni (ed.), Roberto Bolaño: la escritura como tauromaquia, Buenos Aires, Corregidor, 2002, p. 112.

${ }^{4}$ Una tarea laboriosa, aunque no exenta de interés, es la de identificar estos nombres con sus respectivos roles ficcionales de Los detectives salvajes. Por ejemplo, Bolaño se inspiró en Mario Santiago para el personaje de Ulises Lima, en Bruno Montané para el de Felipe Müller y en Juan Esteban Harrington para el de Juan García Madero.
} 
Hacer aparecer las nuevas sensaciones. Subvertir la cotidianeidad.

O.K.

DÉJENLO TODO, NUEVAMENTE LÁNCENSE A LOS CAMINOS ${ }^{5}$

En 1976 se gesta también la antología-revista Pájaro de calor, apoyada por el exiliado español Juan Cervera, y la primera publicación individual de Roberto Bolaño: el cuadernillo Reinventar el amor, un largo poema que se editó en el Taller Martín Pescador con una tirada de 225 ejemplares.

En 1977 se produce la diáspora del infrarrealismo. En ese momento, Bolaño sale otra vez de México, tras la breve experiencia chilena que había vivido en 1973, coincidiendo con el derrocamiento de Salvador Allende y el golpe de Estado de Pinochet. Después de viajar por Europa, se instala en Barcelona. ${ }^{6}$ Sin embargo, sigue colaborando en diversas publicaciones a ambos lados del Atlántico. En octubre-noviembre de 1977 se imprime el único número de la revista Correspondencia Infrarrealista, subtitulada Revista Menstrual del Movimiento Infrarrealista. Un año más tarde, Bolaño crea, con Bruno Montané, una revista y editorial de vida igualmente efímera: Rimbaud Vuelve a Casa, cuyo título parafraseaba uno de los gritos de guerra del infrarrealismo. En 1979, se publica en México la antología Muchachos desnudos bajo el arcoiris de fuego (11 poetas jóvenes latinoamericanos). Entre los antologados figuran tres antiguos infrarrealistas (Mario Santiago, Bruno Montané y el propio Bolaño), aunque el horizonte estético desborda el pasado anhelo de ruptura. En sus versos, Bolaño apunta ya las obsesiones que le acompañarán durante toda su trayectoria: el miedo a "quemar su inspiración", la condena de "enamorarse 100 veces de la misma / muchacha" o la certeza "de una muerte esbelta y temprana". En 1983, la editorial Rimbaud Vuelve a Casa Press presenta otra antología, Regreso a la Antártida, que reúne poemas de Alberto Gallero, Bruno Montané y Roberto Bolaño. En ese mismo año, Montané y Bolaño lanzan la revista Berthe Trépart, en honor de la

\footnotetext{
${ }^{5}$ Roberto Bolaño, "Déjenlo todo, nuevamente. Primer Manifiesto Infrarrealista", Página del Movimiento Infrarrealista de Poesía <http://www.infrarrealismo.com>, s/p. En esta página se puede rastrear una completa genealogía del infrarrealismo mexicano.

${ }^{6}$ De su descubrimiento de Barcelona da noticia el autor en el "Diccionario Bolaño" incluido como anexo de Para Roberto Bolaño: "Barcelona, en el año 77, era una verdadera belleza, una ciudad en movimiento con una atmósfera de júbilo y de que todo era posible. Se confundía la política con la fiesta, con una gran liberación sexual, un deseo de hacer cosas constantemente, que probablemente era artificial, pero, artificial o verdadero, era tremendamente seductor" (cit., p. 86). Como se verá, esta perspectiva idealizada no siempre se corresponde con la que acogen sus versos.
} 
pianista que protagoniza un episodio de Rayuela, la célebre novela de Cortázar. ${ }^{7}$ Desde entonces, Bolaño avanza en solitario y considera el infrarrealismo como un pecado de juventud del que no es necesario arrepentirse, pero que ha quedado sepultado junto con los ideales de un tiempo proclive a la utopía.

Una vez finalizada la aventura infrarrealista, la historia poética del autor se inaugura con Fragmentos de la Universidad Desconocida (1993), Premio Rafael Morales, que puede verse como su primer libro publicado, tanto por su extensión como por su unidad temática. Más tarde aparecen el cuaderno El último salvaje (1995), que vio la luz en México, y los libros Los perros románticos (1995), Premio Ciudad de Irún, y Tres (2000). Los perros románticos conocerá dos reediciones posteriores - en 2000 y 2006- que presentan variantes sustanciales con respecto a su primera versión, pues suprimen algunos poemas e introducen otros que potencian la trabazón interna del libro. Por su parte, Tres reproduce la sección "Prosa del otoño en Gerona", que se había incluido en Fragmentos de la Universidad Desconocida, y añade dos nuevos textos: el poema narrativo "Los neochilenos" y la prosa "Un paseo por la literatura". Al margen de sus divisiones externas, estos libros se caracterizan por la voluntad de reconstruir una biografía fragmentada en múltiples disfraces subjetivos.

Alas obrascitadas se ha sumado recientemente LaUniversidadDesconocida (2007), que no sólo incorpora numerosos inéditos, sino que propone una reordenación de los materiales anteriores. ${ }^{8}$ Este libro se estructura en tres partes, que se corresponden con las zonas de fechas en que se escribieron los poemas: 1970-1980, 1980-1984 y 1987-1994. A su vez, cada una de ellas consta de un número indeterminado de secciones. ${ }^{9}$ La complejidad de este panorama hace que la poesía de Bolaño deba leerse con la cautela de quien se acerca a una

\footnotetext{
${ }^{7}$ El personaje de Berthe Trépart puede interpretarse como síntoma de la soledad, la melancolía y las neurosis del artista contemporáneo. Cortázar también subrayaba la eufonía del nombre de la pianista: "No sabía por qué, le hacía gracia que la pianista se llamara Berthe Trépart"; en Rayuela, Buenos Aires, Editorial Sudamericana, 1968 (8.a), p. 123.

${ }^{8}$ El proceso de formación del libro está minuciosamente detallado en la "Breve historia del libro" que acompaña la edición, a cargo de Carolina López, la viuda del poeta. También se agrega una nota del autor, de 1993, que parece legitimar el orden actual. Por eso, salvo cuando se señale lo contrario, citaré siempre por esta edición (Barcelona, Anagrama, 2007). Para evitar la profusión de notas, indicaré junto a la cita el número de la página correspondiente.

${ }_{9}^{9}$ Entre otras novedades, La Universidad Desconocida gana para el terreno de la poesía, con el título de "Gente que se aleja", la obra ya publicada en 2002 como Amberes. El carácter fronterizo de este texto de juventud, datado en 1980, justifica su adscripción genérica a la prosa poética. No obstante, su clima policiaco tiene numerosas concomitancias con la novela La pista de hielo (1992).
} 
obra provisional, ya que resulta imposible verificar el grado de semejanza entre la idea que el autor tenía de su poesía completa y La Universidad Desconocida. En todo caso, asumidas estas reservas, su lírica ofrece una comunidad de caracteres que permite abordar su sensibilidad estética desde un enfoque global. En este trabajo, analizaré las proyecciones autobiográficas en la poesía de Bolaño atendiendo a tres factores: la descripción del poeta como ser urbano, el paralelismo metafórico entre la figura del escritor y la del detective, y el cultivo del autorretrato como un medio de afrontar la propia identidad.

\section{LA MUSA Del Distrito $5^{\circ}$}

La poesía de Roberto Bolaño se enmarca en la ciudad como hábitat natural del individuo moderno. El locus urbano actúa en un doble sentido. Por un lado, constituye el decorado de sus poemas, un espacio brumoso tras el que se divisa una geografía de calles, barrios y lugares cotidianos. Por otro lado, contiene una naturaleza emotiva que siente con el poeta y que se compadece de su sufrimiento. La ciudad de Bolaño, con unas señas de identidad fácilmente reconocibles, se asocia con Barcelona, que representa la transposición contemporánea de la megalópolis vanguardista. En otros ejemplos, la poliédrica cartografía barcelonesa se sustituye por el barrio antiguo de Gerona o por las avenidas de Ciudad de México, recreadas en la memoria como parte de la mitología personal del autor. Para Bolaño, la metrópoli es un territorio casi siempre hostil, donde se observa el fracaso de organizar la sociedad y donde se advierten los signos de la aceleración de la historia. La revisión del marco urbano le lleva a actualizar algunos tópicos que se han asociado desde antiguo con la ciudad y a incorporar nuevos matices que dotan de singularidad a su mirada.

Una de las plasmaciones recurrentes en Bolaño es la de la ciudad enferma, que desarrolla la secuencia metafórica entre urbe e infierno. Esta ciudad condensa el desarraigo del sujeto y se relaciona con las nociones de alteridad, malditismo y condenación surgidas a finales del siglo XIX. El spleen parisino de Baudelaire es la expresión más nítida del tedio cosmopolita, una abulia que se concreta en una progresiva disolución de la identidad. ${ }^{10}$

\footnotetext{
${ }^{10}$ Ya en su ensayo "Las grandes urbes y la vida del espíritu", escrito en 1903, Georg Simmel destacaba que el fundamento psicológico de los individuos cosmopolitas residía en "el acrecentamiento de la vida nerviosa, que tiene su origen en el rápido e ininterrumpido intercambio de impresiones internas y externas"; en El individuo y la libertad. Ensayos de crítica de la cultura, Barcelona, Edicions 62, 1986, p. 247.
} 
Expulsado del paraíso, al escritor sólo le queda una irrevocable vocación de nostalgia o una voluntad de diferencia que acaba por reactivar la creencia romántica en la excepcionalidad psíquica del artista. La personalidad del poeta se sugiere mediante el símbolo de la lluvia, que metaforiza la soledad en medio de la muchedumbre. Así sucede en los poemas que comienzan "Esperas que desaparezca la angustia" ("Lluvia: sólo espero / Que desaparezca la angustia", p. 15) y "Ahora paseas solitario por los muelles" ("Fumas un cigarrillo negro y por / un momento crees que sería bueno / que lloviese", p. 162). Lo mismo ocurre en las composiciones tituladas "Sangriento día de lluvia" y "Lluvia". Mientras que la primera expresa una amarga letanía dirigida a los desamparados de la sociedad, la segunda recoge las huellas de una ruptura sentimental en un paisaje que encarna el imposible retorno a la naturaleza. En los últimos versos, la ciudad se reduce a su médula significativa:

Ni la lluvia, ni el llanto, ni tus pasos que resuenan en el camino del acantilado importan. Ahora puedes llorar y dejar que tu imagen se diluya en los parabrisas de los coches estacionados a lo largo del Paseo Marítimo. Pero no puedes perderte.

En "Plaza de la estación", la ciudad enferma se perfila como una construcción mental que subvierte los tópicos simbolistas. La realidad visible - el cielo gris, la plaza cercada, el surtidor cubierto de musgo, el arco de hierro - adquiere autonomía al establecerse en la memoria, más allá de la observación empírica:

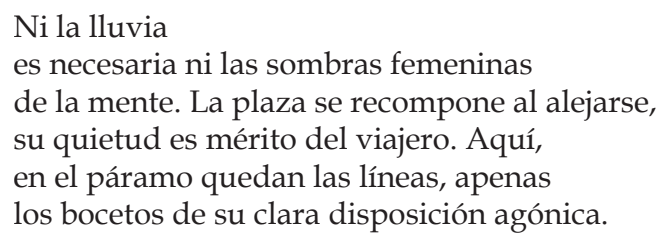

Junto con la ciudad enferma, Bolaño reelabora el escenario de la megalópolis vanguardista, planteada como un vertedero de sueños. Esta ciudad-sumidero, que a menudo se impregna de tintes oníricos, muestra el vértigo de una sociedad que transforma a los sujetos en piezas de un sistema 
deshumanizado. Ya en el expresionismo alemán, la película Metrópolis (1926), de Fritz Lang, había forjado la iconografía de un régimen capaz de anular las aspiraciones individuales en aras del bien colectivo.

La imagen de la ciudad como un monstruo que absorbe los deseos particulares encuentra un interesante desarrollo en la poesía de Bolaño. En su caso, se trata de un lugar con nombre propio: Barcelona. La Barcelona subterránea que descubre el autor emerge en "Calles de Barcelona”, "Tardes de Barcelona" y "Los crepúsculos de Barcelona", improvisados apuntes del natural a propósito de "la ciudad de las genuflexiones y de los cordeles", como se dice en el último de los poemas citados. Con distintos matices, Gerona también adquiere connotaciones pesimistas en "La nieve cae sobre Gerona" y "Prosa del otoño en Gerona". En ellos, Gerona se describe con una adjetivación negativa que remite a la idea de un desierto, un infierno o un laberinto. ${ }^{11}$ Ahora la nieve, como antes la lluvia, alude a un frío que ha de entenderse en un nivel literal y metafórico, en sintonía con la inquietud de quien se siente extranjero en todas partes. Asimismo, la perspectiva caleidoscópica del discurso propone una visión fragmentaria de la realidad en ciertas secuencias no exentas de tremendismo:

La paciencia en Gerona antes de la Tercera Guerra.

Un otoño benigno.

Apenas queda olor de ella en el cuarto...

El perfume se llamaba Carnicería Fugaz...

Un médico famoso le había operado el ojo izquierdo...

También la evocación de México se tiñe a veces de pinceladas apocalípticas. En "Godzilla en México", la figuración distópica de la sociedad actual se mezcla con el ambiente kitsch para articular una fábula donde los seres humanos son los supervivientes de una rara catástrofe. La vinculación entre el Apocalipsis posmoderno y el aquelarre urbano se transmite aquí mediante un diálogo entre el poeta y su hijo. Las coordenadas de ciencia ficción y el tono visionario del inicio desaparecen en un corolario intimista en el que el escritor defiende su actitud de resistencia, tanto en una dimensión pública como privada:

\footnotetext{
${ }^{11}$ Sobre la demarcación espacio-temporal de "Prosa del otoño en Gerona", cf. Jaime Blume, "Roberto Bolaño poeta", en Patricia Espinosa H. (ed.), Territorios en fuga. Estudios críticos sobre la obra de Roberto Bolaño, Santiago de Chile, Frasis, 2003, pp. 151-152.
} 


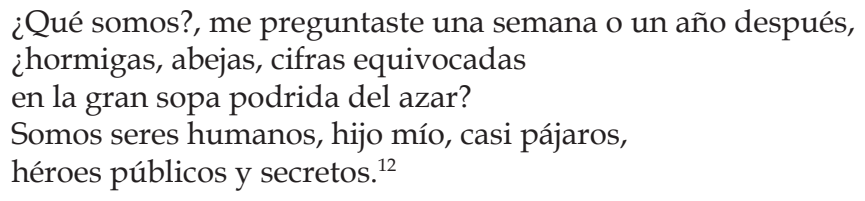

La ciudad enferma y la megalópolis vanguardista no son las únicas maneras de plasmar la realidad urbana según Bolaño. La metrópoli moderna no se limita a una localización estética, sino que se entrelaza con un retrato de los modos de vida contemporáneos, con sus tipos representativos y relatos anecdóticos. Prueba de ellos son algunos poemas referidos a personajes determinados por el entorno en que se hallan: "Dos poemas para Sara", "La Chelita" o las dos composiciones dedicadas a la madre del autor, "Para Victoria Ávalos" y "Victoria Ávalos y yo", en las que los recuerdos personales se confunden con el homenaje a los "proletarios nómadas" perdidos en las ciudades extranjeras. En otras ocasiones, el retablo colectivo se refleja a través de las frases atrapadas al vuelo ("Una escena barcelonesa") o de la indagación en la actitud cívica del sujeto ("¿Qué haces en esta ciudad donde eres pobre y desconocido?"). El diálogo del autor consigo mismo es síntoma de una escisión interna, pero también de una identidad que resulta indisociable del espacio en el que se ubican sus vivencias. Este vínculo se incrementa en aquellos poemas donde la reivindicación de la conciencia urbana se suma a la reivindicación de la clase social en que se integra el poeta. Bolaño transita desde la imagen del paseante baudeleriano hasta la adscripción a un ámbito concreto: el Distrito $5^{\circ}$ (el Raval) de Barcelona, donde residió tras su llegada a España. Sin embargo, esta travesía no es solidaria con la evolución desde un gesto antagónico hasta un gesto cómplice. En Bolaño perdura aún la crítica ante la alienación de las grandes ciudades, aunque su denuncia no se fundamenta en las oposiciones binarias que pautaban el discurso ideológico del socialrealismo: urbano / rural, artificio / naturaleza o deshumanización / humanidad. ${ }^{13}$ La poesía

\footnotetext{
12 Roberto Bolaño, Los perros románticos. Poemas 1980-1998, cit., p. 45.

${ }^{13}$ La posmodernidad ha aprendido a convivir con el mundo urbano como un espacio de complicidad alejado del entusiasmo por el progreso de las vanguardias y de la crítica ideológica del socialrealismo. Sin embargo, los lugares (parques, hoteles, bares) y motivos (taxis, buzones, semáforos) que conforman el mapa de la ciudad de servicios están ausentes de la poesía de Bolaño. Esta visión contrasta con la predominante en la poesía española actual; cf. Pere Pena, "La otra ciudad (Los poetas y la ciudad de fin de siglo)", Scriptura, núm. 10, 1994, pp. 75-91; Manuel Vázquez Montalbán, La literatura en la construcción de la ciudad democrática, Barcelona, Crítica,
} 
ya no es un arma cargada de futuro, sino que adopta nuevas codificaciones simbólicas.

El conflicto entre el autor y su entorno se materializa en el Distrito $5^{\circ}$, que poco a poco va adoptando la fisonomía del extrarradio, un paisaje en el que prima la insatisfacción individual sobre el descontento colectivo. La recreación del suburbio asume las connotaciones de las afueras, del aislamiento o de un exilio interior que sólo alcanza a redimirse mediante la invención literaria. El poder transformador de la escritura cobra relieve en "Las pelucas de Barcelona" ("Sólo deseo escribir sobre las mujeres / de las pensiones del Distrito 5”", p. 24), “Una estatua” ("imágenes lejanas del Distrito $5^{\circ}$... cuando / aún vivías en Barcelona...", p. 104) y "En el Distrito 50 con los sudacas", donde la vida desapercibida del sujeto se mezcla con sus sueños y sus lecturas:

En el Distrito $5^{\circ}$ con los sudacas:

¿Aún lees a los juglares? Sí

Quiero decir: trato de soñar

castillos y mercados Cosas de ese tipo

para después volver a mi piso y dormir

La huella urbana de Bolaño es un aspecto significativo de su configuración lírica. El autor consigue diseñar un territorio caracterizado por la capacidad subversiva de la imaginación frente a la mediocridad circundante. En este proceso radica el prodigio de un arte que logra convertir la realidad en literatura sin traicionar a la primera ni ser infiel a la segunda.

\section{EL POETA COMO DETECTIVE}

La afición de Bolaño por las máscaras literarias puede rastrearse desde sus primeros textos, en los que oculta su identidad tras el disfraz trovadoresco ("Guiraut de Bornelh") o el ademán belicoso de los griegos arcaicos ("San

1998; Laura Scarano, “Poesía urbana: El gesto cómplice de Luis García Montero”, en Luis García Montero, Poesía urbana (Antología 1980-2002), Sevilla, Renacimiento, 2002, pp. 9-32; Ángel L. Prieto de Paula, "La 'construcción de la ciudad' en la poesía española desde la guerra civil al medio siglo", en De manantial sereno. Estudios de lírica contemporánea, Valencia, Pre-Textos, 2004, pp. 111-148; Luis García Montero, "El poeta y la ciudad”, en Los dueños del vacío. La conciencia poética, entre la identidad y los vínculos, Barcelona, Tusquets, 2006, pp. 101-127, y Luis Bagué Quílez, "La presencia de la ciudad", en Poesía en pie de paz. Modos del compromiso hacia el tercer milenio, Valencia, Pre-Textos, 2006, pp. 210-229. 
Roberto de Troya"). Para el autor, la meditación sobre la poesía rara vez adopta la forma del discurso sinuoso y autorreferencial. En lugar de escindirse de lo cotidiano, se integra en la vida privada o se personifica en ciertas figuras representativas de su concepción estética.

Esta original vivificación de la metapoesía cristaliza en el personaje del detective, que reaparece de manera obsesiva en sus composiciones. ${ }^{14}$ Los detectives innominados de Bolaño muestran las posibilidades de la literatura y ofrecen una genealogía artística en la que reconocerse. No obstante, la pesquisa detectivesca está condenada de antemano al fracaso. ${ }^{15} \mathrm{En}$ "El trabajo", el oficio poético se define con diversas imágenes en apariencia inconexas, entre ellas "La mirada desesperada de un detective / frente a un crepúsculo extraordinario" (p. 20). Los detectives irrumpen vencidos por una peripecia vital que los supera: son los "detectives erráticos" de "Ahora tu cuerpo es sacudido por / pesadillas" o el "detective abrumado" de "Fragmentos", un moderno Orfeo que viaja a través de la mitología, la literatura y la muerte. En otros poemas, la presencia del detective se relaciona con un marco alucinado o alegórico, como ocurre en "Bisturí-hostia" y "Los blues taoístas del Hospital Valle Hebrón". En el primero, un anónimo detective recorre los paisajes de Barcelona hasta llegar al Arco de la Mendicidad en el que se hacinan los cuerpos del suburbio. A su vez, en "Los blues taoístas del Hospital Valle Hebrón", el detective se incorpora a la propia biografía como paradigma de un agnosticismo que en Bolaño adquiere categoría generacional. La búsqueda de la verdad se enfrenta ahora con los espejismos de la memoria y con la superficie de las utopías:

\footnotetext{
${ }^{14}$ En una entrevista, Bolaño explicaba su atracción por el oficio de detective, al que equiparaba con el de escritor: "Me hubiera gustado ser detective de homicidios, mucho más que escritor. De eso estoy absolutamente seguro. Un tira de homicidios, alguien que puede volver solo, de noche, a la escena del crimen, y no asustarse de los fantasmas"; Roberto Bolaño, "Final: 'Estrella distante' (Entrevista de Mónica Maristain)", en Entre paréntesis. Ensayos, artículos y discursos (1998-2003), Barcelona, Anagrama, $2005\left(2 .^{a}\right)$, p. 343.

${ }^{15}$ La figura del detective sirve de nexo entre los poemas y la obra en prosa del autor, como manifiestan las analogías entre sus composiciones líricas y el relato "Detectives" (Llamadas telefónicas, 1997) o la novela Los detectives salvajes. Una de las aportaciones de Bolaño a la narración policiaca consiste en desplazar los patrones estructurales y temáticos del género al orden retórico, de tal forma que para él "no se trata tanto de un enigma a develar, como en la novela policial, sino más bien de un secreto que el texto parece esconder"; Ezequiel de Rosso, "Una lectura conjetural. Roberto Bolaño y el relato policial", en Celina Manzoni (ed.), Roberto Bolaño: la escritura como tauromaquia, cit., p. 137. Esta observación resulta también válida para aquellos poemas que deconstruyen los rasgos de la novela negra - testigos, móvil, culpables - en una atmósfera de contornos imprecisos.
} 


\begin{abstract}
Así, tú y yo nos convertimos
En sabuesos de nuestra propia memoria.

$\mathrm{Y}$ recorrimos, como detectives latinoamericanos,

Las calles polvorientas del continente

Buscando al asesino.

Pero sólo encontramos

Vitrinas vacías, manifestaciones equívocas

De la verdad.
\end{abstract}

El paralelismo entre el autor y el detective se desarrolla en varias composiciones en que la reflexión latente en los textos anteriores se hace explícita; así se observa en la serie formada por "Policías", "Soñé con detectives helados", "Los detectives", "Los detectives perdidos" y "Los detectives helados". El universo de la novela negra, cuya difusa acotación espacio-temporal remite al Paul Auster de La trilogía de Nueva York, provoca la superposición de un nivel real y un nivel ficcional. Los detectives deambulan por una cartografía simbólica, pero que no es difícil de trasladar a un plano concreto. "El gran refrigerador de México D.F.", "la ciudad oscura, "el Teatro de la Juventud" y los "cafés y parques / Frecuentados en la adolescencia" son los retazos de una biografía que se puede reconstruir a partir de una tenue trama narrativa. En "Los detectives helados", la pieza que cierra la serie, los "detectives latinoamericanos" siguen el rastro de un crimen que encarna el Espanto como signo de nuestro tiempo. ${ }^{16} \mathrm{~A}$ la falsilla policiaca hay que añadir la distorsión de la identidad que introduce "el espejo convexo de los Arnolfini". El espejo que aparece al fondo del cuadro El matrimonio Arnolfini, de Van Eyck, entronca con la poética del esperpento postulada por ValleInclán. De hecho, la deformación de la realidad resume el sinsentido de la

\footnotetext{
${ }^{16}$ La fascinación de Bolaño por el Mal, como enfermedad endémica de la sociedad, es una constante en sus novelas y relatos. Esta tema adopta diversas formas, desde las delirantes semblanzas de La literatura nazi en América (1996) hasta los informes forenses insertados en 2666 (2004), pasando por la falsa conferencia "Literatura+enfermedad=enfermedad", de El gaucho insufrible (2003). En este último texto, el autor llevaba a cabo una relectura del poema "El viaje", de Baudelaire, en clave de relato de terror: "En medio de un desierto de aburrimiento, un oasis de horror. No hay diagnóstico más lúcido para expresar la enfermedad del hombre moderno. Para salir del aburrimiento, para escapar del punto muerto, lo único que tenemos a mano, y no tan a mano, también en eso hay que esforzarse, es el horror, es decir el mal"; en El gaucho insufrible, Barcelona, Anagrama, 2003, p. 151.
} 
existencia. ${ }^{17}$ Por eso, el horizonte visual de "Los detectives helados" - los "ojos abiertos", "una sola mirada", "nuestras perspectivas" - se instala en un territorio donde los sueños se convierten en pesadillas:

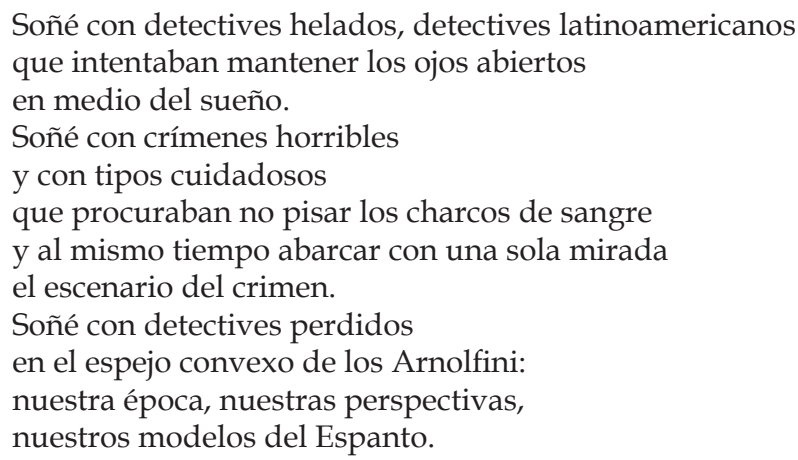

El motivo del sueño literario, de ascendencia quevediana, surca "Un paseo por la literatura", publicado en Tres y no recogido después en La Universidad Desconocida. En esta ocasión, el ambiente detectivesco es la excusa para elaborar un canon personal. Bolaño se disfraza de "detective latinoamericano" para transitar entre los nombres de sus autores admirados: Georges Perec, Macedonio Fernández, Efraín Huerta, Enrique Lihn, Thomas de Quincey, Philip K. Dick, Arquíloco, Nicanor Parra, César Vallejo, Franz Kafka, Mark Twain, Roque Dalton, Walt Whitman, el Marqués de Sade, Charles Baudelaire o James Matthew Barrie. Partiendo de la intertextualidad, la literatura se interioriza como un aspecto relevante de la propia experiencia.

Los detectives de Bolaño no se contentan con habitar los versos con su presencia inquietante. El poeta construye un espacio que actúa como trasfondo de la ficción: la Universidad Desconocida. Esa Universidad Desconocida se menciona por primera vez en el poema "Entre Friedrich von Hausen", donde el minnesinger alemán que da título a la pieza se disuelve en una Barcelona suburbial poblada por los antihéroes del lumpen. Desde ese momento, la Universidad Desconocida integra el imaginario estético de Bolaño y dota a su

\footnotetext{
${ }^{17}$ Este recurso ya lo había ensayado el autor estadounidense John Ashbery en su poema-libro Autorretrato en un espejo convexo (Self-Portrait in a Convex Mirror, 1975), donde la reflexión sobre la identidad propiciaba una indagación en el proceso de escritura.
} 
discurso de un halo de misterio. Así, en "Es de noche y estoy en la zona alta", el soporte confesional se desdibuja en las fronteras entre invención y realidad. El autor que disfruta de una animada compañía y bebe café con leche en un restaurante de la zona alta puede estar

solo y borracho

gastando mi dinero en uno de los límites

de la universidad desconocida.

La suspensión de las referencias favorece la interpretación de la Universidad Desconocida como el emblema de un deseo incumplido. En ese sentido, representa algo similar al albatros de Baudelaire o la Quimera de Cernuda: el anhelo de remontarse sobre las cortapisas de la realidad, aun a sabiendas de que el empeño puede resultar perfectamente vano. Otros textos proporcionan nuevos matices en la búsqueda de esa Universidad Desconocida. Por ejemplo, el fragmento final de "Prosa del otoño en Gerona" asocia el descubrimiento de la esperanza y el encuentro de uno de los pabellones de la Universidad Desconocida: "Esta esperanza yo no la he buscado. Este pabellón silencioso de la Universidad Desconocida" (p. 287). Por último, "Un paseo por la literatura" incluye una escueta alusión a la Universidad Desconocida en el momento en el que Bolaño sueña con uno de sus maestros, el poeta chileno Enrique Lihn:

¿Y quién estaba al otro lado de la puerta? Enrique Lihn con una botella de vino, un paquete de comida y un cheque de la Universidad Desconocida. $^{18}$

La Universidad Desconocida es un símbolo plural que encierra la clave de la aventura literaria, más allá de los significados impuestos por la tradición. Su importancia como palabra-aleph de Bolaño justifica que su poesía

\footnotetext{
${ }^{18}$ Roberto Bolaño, Tres, Barcelona, El Acantilado, 2000, p. 83. La aparición fantasmagórica de Enrique Lihn protagoniza "Encuentro con Enrique Lihn", el relato final de Putas asesinas (2001), que se abre con la siguiente anotación: “En 1999, después de volver de Venezuela, soñé con que me llevaban a la casa donde estaba viviendo Enrique Lihn, en un país que bien pudiera ser Chile y en una ciudad que bien pudiera ser Santiago"; en Putas asesinas, Barcelona, Anagrama, 2003 (3. a), p. 217. Lihn también había trazado una breve semblanza de Bolaño, reproducida en la solapa de Fragmentos de la Universidad Desconocida: “El auctor Bolaño, el personaje que actúa en sus versos y quizá sea él, es un adolescente un poco malandra, medio desaforado, obsceno, perplejo, y como se dice aquí, con su media voladura"; en Fragmentos de la Universidad Desconocida, Talavera de la Reina, Ayuntamiento, 1993.
} 
reunida haya recibido este título. ${ }^{19}$ Del mismo modo, la máscara del detective no es un mero disfraz cultural. Por el contrario, la fabulación detectivesca desemboca en un ejercicio de auto-conocimiento que no pretende evitar ni la identificación emotiva ni la impudicia sentimental.

\section{Los rostros De Roberto Bolaño}

El desdoblamiento entre el poeta y el sujeto poético desaparece en varios poemas que fluctúan entre la autobiografía y el autorretrato. El propio escritor diferenciaba entre ambos géneros y confesaba al respecto, en una entrevista concedida a Carmen Boullosa:

Un autorretrato exige una cierta voluntad, un ego que se mira y remira, un interés manifiesto por lo que uno es o ha sido. La literatura está llena de autobiografías, algunas muy buenas, pero los autorretratos suelen ser muy malos, incluso los autorretratos poéticos, que a simple vista parece una disciplina literaria más apta para el autorretrato que la narrativa. ${ }^{20}$

En la poesía de Bolaño abundan los autorretratos, con distinto grado de semejanza entre el autor y el hablante. Sin embargo, ni siquiera sus autorretratos más directos se limitan a la autocontemplación estética. El omphalismo inherente al género suele sacrificarse en una propuesta más amplia, donde el individuo asume las expectativas de un grupo generacional, un momento histórico o una clase social. No se trata tanto de difuminar los rasgos personales en la colectividad como de reivindicar una intimidad en conflicto con el medio, que toma conciencia de su lucha y que cifra su supervivencia en las posibilidades de mantenerse, heroicamente, frente al sistema de valores establecido. Se configura así una suerte de épica subjetiva que no se cumple en el egotismo, sino que suele abrir un resquicio al tiempo en que le ha tocado vivir al autor. ${ }^{21}$

\footnotetext{
${ }^{19}$ Para completar la configuración del poeta como detective, falta un icono que simboliza la fuerza motriz del destino o el fatum trágico: el automóvil negro de sus composiciones. El motivo del viaje es la excusa de una road movie colectiva donde la muerte se proyecta en el paisaje, como una profecía que lleva implícito su cumplimiento. Así se advierte en el poema "Los neochilenos", una truncada epopeya generacional que narra las desventuras de un grupo de rock cuyos componentes guardan claras similitudes con los infrarrealistas.

${ }^{20}$ Carmen Boullosa, "Carmen Boullosa entrevista a Roberto Bolaño", cit., p. 110.

${ }^{21}$ Esta idea conduce a una reformulación del pacto autobiográfico, en los términos definidos por Lejeune. Para este crítico, el pacto autobiográfico consistía en un contrato entre autor y lector. Según las normas de ese contrato, el primero se compromete a dar cuenta de su vida con la mayor fidelidad posible. Sin embargo, la aceptación de que el género autobiográfico es un género
} 
Los retratos cotidianos de Bolaño aportan diversos datos que permiten reconstruir sus experiencias. Entre estas pistas, cabe destacar la mención del camping Estrella de Mar, de Castelldefels, donde trabajó como vigilante nocturno entre 1978 y 1981.22 Este decorado aparece ya en el poema "Según Alain Resnais": "leo esto en la noche del camping / Estrella de Mar" (p. 35). La alusión al camping se reitera en ciertos pasajes de "Gente que se aleja" y en las composiciones "Amanece en el camping" y "Otro amanecer el camping Estrella de Mar", dos escenas de tedio cotidiano emparentadas con algunas facetas del realismo sucio norteamericano. La segunda concluye con un desenlace anticlimático que sintetiza el estado anímico del poeta:

Dulce estilo nuevo de la primavera

10 grados sobre cero

a las 6 a.m.

$$
\text { (p. 145). }
$$

Un paso más en el diseño del autorretato es el de la autonominación, como indicio de una biografía aparentemente verificable. En su poesía, es muy común que Bolaño se presente con su nombre, su edad o sus rasgos físicos. Mediante esta estrategia discursiva se aspira a construir un sujeto en el que quedan homologados el hablante y el autor. Dicho mecanismo favorece una afirmación del yo poético alejada de las fisuras posmodernas, pero al mismo tiempo potencia la ironía y otros recursos afines. ${ }^{23}$ Las complejas redes de la autonominación se evidencian en los numerosos robertos bolaño que

contractual no anula el estatuto ficcional del sujeto ni altera la convención literaria que supone el acto de escritura; cf. Philippe Lejeune, El pacto autobiográfico y otros estudios, Madrid, Megazul / Endymión, 1994.

${ }^{22}$ El nombre del camping se sustituye por el de Stella Maris en La pista de hielo (1992). Por otra parte, este escenario reaparece en Soldados de Salamina (2001), de Javier Cercas, cuando el narrador contacta a lo largo de su investigación con un tal Roberto Bolaño. En una de las conversaciones entre ambos, Bolaño afirma que, más allá de la correspondencia entre realidad y ficción, el resultado final de toda narración reside en su veracidad: "Da lo mismo - replicó Bolaño - . Todos los buenos relatos son relatos reales, por lo menos para quien los lee, que es el único que cuenta"; en Soldados de Salamina, Barcelona, Tusquets, $2001\left(4^{\mathrm{a}}{ }^{\mathrm{a}}\right)$, p. 166.

${ }^{23}$ Cf. Laura Scarano, "Travesías de la enunciación en las poéticas sociales españolas de posguerra", Cuadernos para Investigación de la Literatura Hispánica, núm. 26, 2001, pp. 265-276. Con respecto a este procedimiento en los poetas españoles, Jaime Siles señalaba que su sentido principal era el de la "autoelegía, ironización o distanciamiento de ese yo ahora nominado y que sólo conserva con su igual la coincidencia en su homonimia"; en "Dinámica poética de la última década", Revista de Occidente, núms. 112-113, julio-agosto de 1991, p. 168. 
comparecen bajo la identidad única de Roberto Bolaño. El trasiego entre la primera persona y el alter ego se plasma en "Devoción de Roberto Bolaño", una secuencia en tercera persona donde el poeta analiza su situación a finales de 1992, y “El regreso de Roberto Bolaño", un relato en primera persona sobre su itinerario por la memoria chilena.

El recuerdo de la juventud da paso a la prospección del futuro inmediato en los textos que Bolaño dedica a su hijo: "Cuatro poemas para Lautaro Bolaño" y "Dos poemas para Lautaro Bolaño". En los "Cuatro poemas", el autor hace un breve recuento de sus vínculos afectivos. El transcurso del tiempo está cifrado en cuatro palabras - la familiaridad, las pesadillas, las sombras y las facciones - que determinan la complicidad entre el escritor y su hijo. Las palabras para Lautaro se conciben como un conjunto de recomendaciones para caminar por la vida. El modelo existencial se sustituye por la plantilla literaria en los "Dos poemas", que recogen un consejo y una súplica. El consejo, "lee a los viejos poetas", expresa el deseo de que Lautaro aprenda a residir en la ficción, mientras que la súplica es una petición para que los libros que forman la biblioteca del padre velen por su hijo:

- Así pues, la consigna es ésta:

Resistid queridos libritos

Atravesad los días como caballeros medievales

Y cuidad de mi hijo

En los años venideros

(p. 435).

Finalmente, la poesía de Bolaño incluye algunos autorretratos en el sentido estricto del término: "Autorretrato a los veinte años", los dos poemas titulados "Autorretato" y "Retrato en mayo, 1994". En ellos, el poeta opera como el pintor que se refleja en varios momentos de su vida con el objetivo de analizar su evolución, lo que perdura de sus antiguas creencias y los ideales que se han ido perdiendo en el camino. "Autorretrato a los veinte años" culmina con una emocionada epifanía generacional:

Y me fue imposible cerrar los ojos y no ver aquel espectáculo extraño, lento y extraño, aunque empotrado en una realidad velocísima: miles de muchachos como yo, lampiños 
o barbudos, pero latinoamericanos todos, juntando sus mejillas con la muerte. ${ }^{24}$

(p. 346).

El primero de los poemas titulados "Autorretrato", sin descender a la prosopografía, enriquece la etopeya con algunas consideraciones que se corresponden inequívocamente con el autor, como la fecha y lugar de su nacimiento ("Nací en Chile en 1953") o su experiencia en Ciudad de México, a la que se menciona de manera indirecta ("la región más transparente del mundo"). En el desenlace, Bolaño inserta el motivo especular como un medio de introducirse a sí mismo en la descripción:

Entre una punta y otra sólo veo

mi propio rostro

que sale y entra del espejo

repetidas veces.

Como en una película de terror.

¿Sabes a lo que me refiero?

Aquellas que llamábamos de terror psicológico. ${ }^{25}$

(p. 430).

El segundo de sus autorretratos oscila entre la evocación de un pasado idealizado y la mirada a un presente en el que no queda nada de las amistades infantiles de antaño. Por tanto, la nostalgia se resuelve en la constatación de que todo lo sólido se desvanece en el aire:

Valientes y audaces, como para no morir nunca, mi pandilla siguió peleando

\footnotetext{
${ }^{24}$ El sentimiento de derrota preside toda la obra del escritor, como Bolaño admitía en su "Discurso de Caracas", escrito tras la obtención del premio Rómulo Gallegos por Los detectives salvajes: "en gran medida todo lo que he escrito es una carta de amor o de despedida a mi propia generación, los que nacimos en la década del cincuenta [...] y entregamos lo poco que teníamos, lo mucho que teníamos, que era nuestra juventud, a una causa que creímos la más generosa de las causas del mundo y que en cierta forma lo era, pero que en la realidad no lo era"; en Entre paréntesis. Ensayos, artículos y discursos (1998-2003), cit., p. 37.

${ }^{25}$ Los motivos especulares son frecuentes en la poesía de Bolaño. De ello da prueba la referencia antes citada al espejo de los Arnolfini - una imagen que se reitera en "Cuatro poemas para Lautaro Bolaño" - o el símbolo polisémico del caleidoscopio en "Prosa del otoño en Gerona". El espejo se transforma en metáfora del individuo en soledad, de un autoconocimiento que se realiza, inevitablemente, en el acto de escritura. Sobre el papel del espejo como emblema de la identidad en la poesía española reciente, cf. Luis Martín-Estudillo, "El sujeto (a)lírico en la poesía española contemporánea y su trasfondo Barroco", Hispanic Review, núm. 73.3, verano de 2005, pp. 351-370.
} 
mientras los autobuses mataban a los niños solitarios.

Así, sin darnos cuenta,

lo fuimos perdiendo todo. ${ }^{26}$

(p. 431).

Por último, "Retrato en mayo, 1994", prescinde del prefijo auto en la medida en que no propone un ejercicio autorreflexivo, como en los casos anteriores, sino una proyección del autor en su hijo Lautaro. Escrito con motivo del cuarto aniversario de Lautaro, el poema se inicia en el momento en que "Los autorretratos de Roberto Bolaño" dejan paso a "los autorretratos de Lautaro Bolaño". El discurso se plantea como una posdata lírica que es al mismo tiempo un réquiem por las derrotas colectivas y un canto esperanzado que aspira a cumplirse en el futuro. De este modo, el escritor expresa el deseo de que las antiguas utopías todavía tengan porvenir en las generaciones venideras:

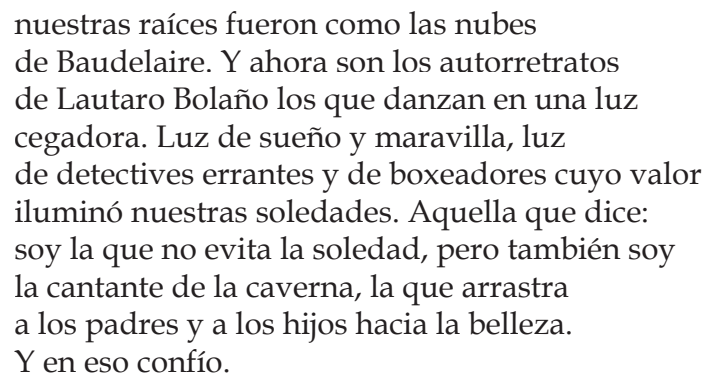

(p. 436).

\section{SIN MIEDO NI ESPERANZA}

En definitiva, los distintos trasuntos subjetivos de Roberto Bolaño muestran el conflicto ante un entorno hostil. El autor intenta escapar de la liquidación del pasado y ve en la literatura una herramienta de resistencia estética con la que abrir territorios en fuga. La defensa de la imaginación en medio de la cartografía urbana, la invención de los detectives como máscara

\footnotetext{
${ }^{26}$ En muchos de sus poemas, Bolaño reformula la amarga lección de Aullidos (Howl, 1956), de Allen Ginsberg, uno de los plantos generacionales más impresionantes de la literatura contemporánea. No obstante, Bolaño reemplaza la letanía beat por el fraseo breve y entrecortado.
} 
del egotismo o la asunción descarnada del autorretrato suponen tres maneras diferentes de enfrentarse a la realidad. Sin embargo, en todas estas identidades palpita un yo poliédrico, heredero de los debates de la modernidad pero renuente a aceptar la ficcionalización posmoderna. ${ }^{27}$ La poesía de Bolaño reacciona ante las aporías del pensamiento débil y del fin de la historia, pues es evidente que la historia continúa en cada uno de los personajes desheredados a los que él supo prestarles su voz.

Roberto Bolaño recordaba a menudo que había nacido el mismo año en que murió Dylan Thomas, el poeta galés que escribió su Portrait of the Artist as a Young Dog (1940) sobre la falsilla del joyciano Portrait of the Artist as a Young Man (1916). A lo largo de sus versos, Bolaño elaboró su peculiar Retrato del artista como perro romántico, un constante proceso de aprendizaje estético y vital al que se entregó incondicionalmente. En un "Autorretrato" en prosa, redactado en marzo de 2001, el autor se definía con una frase que era una apasionada declaración de amor a la literatura: “Soy mucho más feliz leyendo que escribiendo". El lector también está invitado a entrar en el campo de batalla. Para ello basta con acercarse a la obra de Bolaño como él habría querido: sin miedo ni esperanza.

\footnotetext{
${ }^{27}$ Dionisio Cañas afirma que el sujeto posmoderno se caracteriza por mantener una relación desengañada frente a la tradición y por propugnar un estrecho compromiso con el pensamiento posmetafísico; cf. Dionisio Cañas, "El sujeto poético posmoderno", Ínsula, núms. 512-513, agosto-septiembre de 1989, pp. 52-53. Si bien la desmitificación de la herencia literaria suele producirse en la poesía de Bolaño, difícilmente puede observarse en él una respuesta acorde con los valores posmodernos de la transitoriedad, el consumo o la despersonalización.
} 


\section{BibLIOGRAFÍA}

Bagué Quílez, Luis, "La presencia de la ciudad", en Poesía en pie de paz. Modos del compromiso hacia el tercer milenio, Valencia, Pre-Textos, 2006, pp. 210-229.

Blume, Jaime, "Roberto Bolaño poeta”, en Patricia Espinosa H. (ed.), Territorios en fuga. Estudios críticos sobre la obra de Roberto Bolaño, Santiago de Chile, Frasis, 2003, pp. 149-166.

Bolaño, Roberto (1976), "Déjenlo todo, nuevamente. Primer Manifiesto Infrarrealista”, Página del Movimiento Infrarrealista de Poesía <http://www.infrarrealismo. com>, s/p.

Bolaño, Roberto, Fragmentos de la Universidad Desconocida, Talavera de la Reina, Ayuntamiento, 1993.

Bolaño, Roberto, Tres, Barcelona, El Acantilado, 2000.

Bolaño, Roberto, (2001), Putas asesinas, Barcelona, Anagrama, 2003 (3. $\left.{ }^{a}\right)$, p. 217.

Bolaño, RoBerto, El gaucho insufrible, Barcelona, Anagrama, 2003.

Bolaño, Roberto, (2004), Entre paréntesis. Ensayos, artículos y discursos (1998-2003), Barcelona, Anagrama, 2005 (2. $\left.{ }^{a}\right)$.

Bolaño, Roberto, Los perros románticos. Poemas 1980-1998, Barcelona, El Acantilado, 2006.

Bolaño, Roberto, La Universidad Desconocida, Barcelona, Anagrama, 2007.

Boullosa, CARmen, “Carmen Boullosa entrevista a Roberto Bolaño”, en Celina Manzoni (ed.), Roberto Bolaño: la escritura como tauromaquia, Buenos Aires, Corregidor, 2002, pp. 105-113.

CAÑAS, Dionisio, “El sujeto poético posmoderno", Ínsula, núms. 512-513, agosto-septiembre de 1989, pp. 52-53.

Cercas, Javier, Soldados de Salamina, Barcelona, Tusquets, $2001\left(4 .^{a}\right)$.

Cortázar, Julio (1963), Rayuela, Buenos Aires, Editorial Sudamericana, 1968 (8. a).

García Montero, Luis, "El poeta y la ciudad", en Los dueños del vacío. La conciencia poética, entre la identidad y los vínculos, Barcelona, Tusquets, 2006, pp. 101-127.

Gimferrer, Pere, "Presentación", en Roberto Bolaño, Los perros románticos. Poemas 19801998, Barcelona, El Acantilado, 2006, pp. 7-8.

Herralde, Jorge, Para Roberto Bolaño, Barcelona, El Acantilado, 2005.

Lejeune, Philippe (1975), El pacto autobiográfico y otros estudios, Madrid, Megazul / Endymión, 1994.

Martín-Estudillo, Luis, “El sujeto (a)lírico en la poesía española contemporánea y su trasfondo Barroco", Hispanic Review, núm. 73.3, verano de 2005, pp. 351-370. 
Pena, Pere, "La otra ciudad (Los poetas y la ciudad de fin de siglo)", Scriptura, núm. 10, 1994, pp. 75-91.

Prieto de Paula, Ángel L., “La 'construcción de la ciudad' en la poesía española desde la guerra civil al medio siglo", en De manantial sereno. Estudios de lírica contemporánea, Valencia, Pre-Textos, 2004, pp. 111-148.

Rosso, Ezequiel de, "Una lectura conjetural. Roberto Bolaño y el relato policial”, en Celina Manzoni (ed.), Roberto Bolaño: la escritura como tauromaquia, Buenos Aires, Corregidor, pp. 133-143.

SCARANO, LaUra, "Travesías de la enunciación en las poéticas sociales españolas de posguerra", Cuadernos para Investigación de la Literatura Hispánica, núm. 26, 2001, pp. 265-276.

Scarano, Laura, "Poesía urbana: El gesto cómplice de Luis García Montero", en Luis García Montero, Poesía urbana (Antología 1980-2002), Sevilla, Renacimiento, 2002, pp. 9-32.

Siles, Jaime, “Dinámica poética de la última década”, Revista de Occidente, núms. 112-113, julio-agosto de 1991, pp. 149-169.

Simmel, Georg, El individuo y la libertad. Ensayos de crítica de la cultura, Barcelona, Edicions 62, 1986.

VÁzquez Montalbán, Manuel, La literatura en la construcción de la ciudad democrática, Barcelona, Crítica, 1998. 